\title{
François Truffaut's Jules and Jim and the French New Wave, Re-viewed
}

ROBERT J. CARDULLO

University of Michigan

\begin{abstract}
Truffaut's early protagonists, like many of those produced by the New Wave, were rebels or misfits who felt stifled by conventional social definitions. His early cinematic style was as anxious to rip chords as his characters were. Unlike Godard, Truffaut went on in his career to commit himself, not to continued experiment in film form or radical critique of visual imagery, but to formal themes like art and life, film and fiction, and art and education. This article reconsiders a film that embodies such themes, in addition to featuring characters who feel stifled by conventional social definitions: Jules and Jim.
\end{abstract}

Keywords: François Truffaut; French film; New Wave; Jules and Jim; HenriPierre Roché

\section{Resumen}

Los primeros protagonistas de Truffaut, como muchos de los producidos por la New Wave, eran rebeldes o inadaptados que se sentían agobiados por las convenciones sociales convencionales. Su estilo cinematográfico temprano estaba tan ansioso por romper moldes como sus personajes. A diferencia de Godard, Truffaut continuó en su carrera comprometiéndose, no a seguir experimentando en forma de película o crítica radical de las imágenes visuales, sino a temas formales como el arte y la vida, el cine y la ficción, y el arte y la educación. Este artículo reconsidera una película que encarna dichos temas, además de presentar personajes que se sienten ahogados: Jules y Jim.

Palabras clave: François Truffaut, cine francés, New Wave; Jules and Jim, Henri-Pierre Roché.

\section{History, Truffaut, and the French New Wave}

The political uncertainties of postwar France, the Vietnamese and Algerian wars, the growth of ideological disillusion almost into an ideology, a conviction of sterility 
and vacuum in society and in traditional art: all of these produced the French New Wave, a group of young people who liberated themselves through film in the late 1950s. At bottom less a wave than an epidemic of faith and of desperation-a desperate hope that cinema might prove to be an answer to much that was harassing French society and culture - the New Wave consisted of a group of filmmakers who, in a burst of creative energy, turned out their first feature films between 1958 and 1960. The movement owes its considerable international reputation largely to the work of François Truffaut, JeanLuc Godard, and Alain Resnais, but these are not the only names to be mentioned in this regard. The richly productive period that began with Claude Chabrol's Le beau Serge (1958) witnessed the emergence of a host of talented moviemakers, among them Éric Rohmer, Jacques Rivette, Agnès Varda, Chris Marker, Jean-Pierre Melville, Georges Franju, and Jacques Demy.

With the exception of a few such as Alexandre Astruc, Roger Vadim, and Louis Malle, none of these artists served conventional apprenticeships as assistant directors or writers in commercial cinema, and it is partly for this reason that their work is remarkably free of the slick, confectionery aspects of pre-World War II French studio products. On the other hand, the majority of these directors did spend time making short films or working on documentaries (or both), and this experience frequently lends to their work an air of cinéma vérité. Their pictures tend to have a handheld look, a roughness of texture, and a cinematic style influenced by the practical solutions employed in low-budget enterprises: improvisation, inexpensive shooting techniques (through the use of lightweight, easily portable equipment), on-location filming, stories with contemporary settings, and the use of non-professionals or in any case non-stars whenever possible.

The New Wave had its roots in the critical writings of young film enthusiasts who, in the early 1950s, served their theoretical apprenticeship under the guidance of André Bazin, the founder of the journal Cahiers du cinéma. Retreating a generation to the 1930s of Jean Renoir and Jean Vigo, where they located the zest and spontaneity of what they considered to be the authentic French tradition, these critics-become-directors rejected "papa's cinema," the old-fashioned, worn-out format of smooth but impersonal, studio-bound filmmaking - ornately staged, heavily plotted, and over-scriptedassociated with names like René Clair, Marcel Carné, Max Ophüls, and René Clément. Conversely, they endorsed a free, more individualistic style of shooting independent of the restrictions of established industry practices and featuring, above all, auteurist direction. Truffaut himself coined the phrase "politique des auteurs" in Cahiers $d u$ cinéma in January 1954, and this was a politics or theory holding that the movie director, the equal of artists in other forms, should be the "author" of his work and as such the major creative force behind every one of his cinematic endeavors, displaying a personal stylistic signature visible from film to film.

Such a force was Truffaut, who, like the young Vigo and the young Renoir, built his early work on the central artistic idea of freedom, both in human relationships and film technique. Truffaut's early protagonists, in films such as The 400 Blows (1959), Shoot the Piano Player (1960), Jules and Jim (1962), and The Wild Child (1969), were rebels, loners, or misfits who felt stifled by conventional social definitions. And his early cinematic style was as anxious to rip chords as his characters were. Unlike his friend and contemporary Godard, Truffaut went on in his career to consistently commit himself, not to continued experiment in film form or radical critique of visual imagery, but to highly formal themes like art and life, film and fiction, and art and education. He seemed to believe that his commitment to formal aesthetic excellence would eventually serve the political purposes that powerful art always serves, and that to betray his own 
artistic powers to make programmatic statements would perhaps have led to his making of bad art — and bad statements. Like Renoir, then, Truffaut saw the creation of film art, of any art, as a genuinely humane and socially meaningful response to the potentially chaotic disorder of formless reality.

\section{Jules and Jim}

Let me now consider one of those humane and meaningful artistic responses, Jules and Jim. This film is one of the masterpieces of the French New Wave, if not the highest achievement of that movement. In some respects, however, Jules and Jim is not a characteristic New Wave film: whereas most New Wave pictures sought to express the rhythms of their own epoch with complete freshness, Truffaut in this film retreated to the past. Opening brightly in La Belle Époque and closing in the grim era of the Depression and the rise of Hitler, Jules and Jim chronicles twenty-two years in the lives of its characters. But in its own, telescopic way this 1962 film is faithful to the existentialist ethic and aesthetic of its period, for no New Wave film strives more obviously for authenticity in its quest to tap the feelings of a liberated generation whose morality (particularly in the wake of the Holocaust and French collaboration with the Nazis) had to be achieved on the run.

Based on the 1953 semi-autobiographical novel by Henri-Pierre Roché, Jules and Jim combines the celebration of human freedom and sheer joy in filmmaking - each of which characterized the New Wave - with the themes of obsessive, antagonistic love and personal (as opposed to societal) morality. Like the enigmatic, smiling face of the woman sculpted in stone that first transfixes the film's heroes and then initiates their mythic quest, Jules and Jim remains an ever-elusive, ever-seductive image of the need to preserve love and friendship - friendship between two men, love à trois - against the erosions of time and doubt. Using in medley virtually every resource the medium knows - montage or rapid cutting, panning, full-shot framing, jump cuts, tilting, zoom shots, swish pans, masking shots, close-ups, long shots (at times from a helicopter), handheld camera movement, tracking shots backward and forward, freeze frames, irises, and even, from the silent cinema, a burlesqued title card-Truffaut thus introduces in this picture a theme that reappears throughout his canon: that of the problematic (yet inevitable) form of the couple-relationship and the destructive, potentially tragic conflict that can beset all marriages.

The story begins in 1912 with a rapid montage sequence while the voice-over narrator introduces the viewer to a pair of carefree, carefully contrasted young writertranslators, Jim (Henri Serre, imbued with melting standoffishness), a tall, dark, notquite-dashing Parisian, and Jules (Oskar Werner, full of pained charm), a rather short, blond, shy Austrian and a stranger to the French capital. "Everyone called them Don Quixote and Sancho Panza," the narrator tells us. When we first meet them, they are living out a genial but somewhat lackluster bohemianism, brimming with talk about writing and women. While viewing slides at the home of an acquaintance, Albert (Boris Bassiak), the two friends become enraptured by the mysterious image of a woman's head carved in stone. They immediately go to visit an open-air museum on a Greek island in the Adriatic, where they can gaze in person at her disdainful yet beautiful smile, which Truffaut presents through a dramatic series of zooms, pans, and tracking shots circling around the stone figure. 


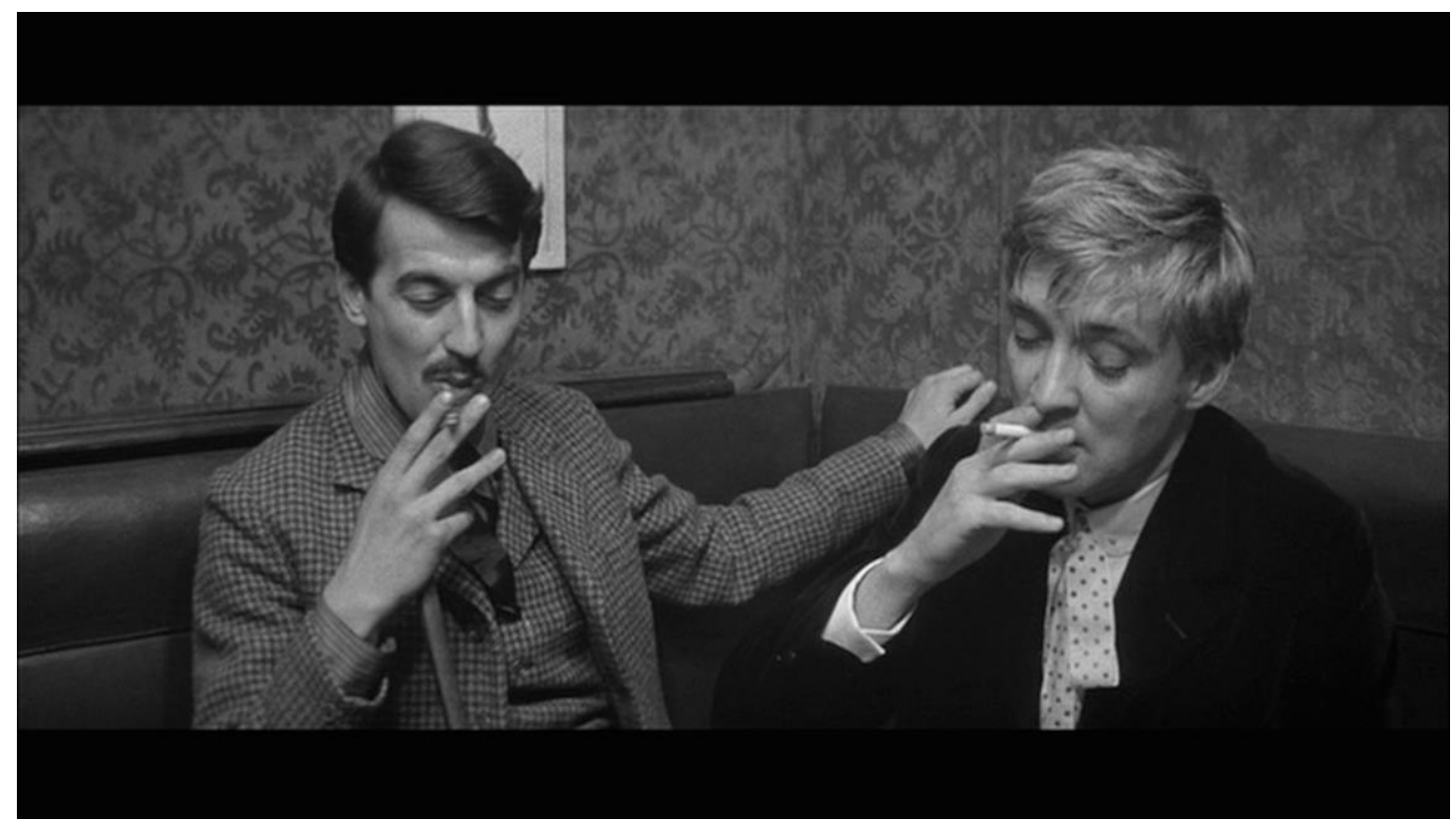

Not long after, Jules invites Jim to meet three girls visiting Paris, one of whom bears an uncanny resemblance-reinforced by Truffaut's repetition of the island montage - to the statue. The sculpture-come-to-life is Catherine (Jeanne Moreau), and she infatuates both men. Indeed, for all their love of books, these pals come alive only when they meet this magnificently desirable and dangerous young woman. And, although the film is named after them, its center or animating force is Catherine, around whom they circle irresistibly. She is a creature both utterly timeless (as we see her visage in the slide of a Greek statue) and forever changing - at different points, she plays the roles of Chaplinesque tramp and street tough, beguiling vamp and doting mother. Passionate and iconoclastic, Catherine is, in fact, the only true free spirit among these three. Just as the men put their talent into their art, so she puts her genius into living - or perhaps into claiming for herself the reckless male freedoms that women have traditionally been denied. Time and again in this film, she literally dresses herself in the garb of masculinity.

On paper, the mercurial Catherine seems an implausibly grandiose conception, a woman both giddy and tragic, proto-feminist and male-dominated, driven by Eros and Thanatos. But as played by Moreau, a pop-eyed siren with the ferocity of Bette Davis and the kitty-cat wiles of Tuesday Weld, Catherine becomes one of the modern movies' triumphant characterizations - the anima as autocrat. Whether playing with vitriol or jumping into the Seine, she elevates capriciousness to an existential principle. When Jim says he understands her, she replies, "I don't want to be understood." And this is absolutely true. She comes into Jules and Jim's lives under the aegis of art, and they appear to create her by investing her with the properties that both attract them to her and divide them from each other. For her part, Catherine, being human, cannot resist her own apotheosis. Thus, from the beginning, she commands Jules and Jim, and her mere wishes become elevated to the level of a philosophical program: utter liberation.

Jules, who has been unlucky in love while away from home, begins to court Catherine-with his friend's blessing. Her independence, which Jules attributes to Catherine's mixed parentage (her father was a French aristocrat, her mother, a lowerclass Briton), fascinates Jim, but her freedom and spontaneity rather overwhelm Jules. (Jules himself, by the way, is designated a Jew in Roché's novel but not in the film.) At her whim, they set up residence in the southern French countryside; when she decides 
that she misses Paris, they instantly return. The moment the men ignore her, Catherine rebels - either playfully, as when she slaps Jules for not responding to her jokes, or disturbingly, as when she suddenly leaps into the Seine to protest their disparaging remarks about women following the production of August Strindberg's play Miss Julie (1888). Jules is frightened by this strange, ominous act; Jim admires it, and draws Catherine's leap from memory the next day.

In time, Jules's innocent charm and bemused tolerance of Catherine's impulsiveness win her over, and she accepts his proposal of marriage shortly before the outbreak of World War I. "You haven't known a lot of women, but I have known many men," she tells Jules. "It balances out, so perhaps we'd make a good couple." The war-presented in a stunning montage of archival footage, much of it stretched to Scope dimensions - divides the film into two parts and separates not only Catherine and Jules, but also the latter and Jim, whose greatest concern is to avoid killing each other. (The Great War is so graphically documented that it brutalizes the earlier sentiments of the film, tossing its characters from their merry-go-round down to the ground, where they land, still and stunned.) Jules writes beautiful, erotic love letters to Catherine; Jim stays with his patient girlfriend, Gilberte, while home on leave. In a poignant reunion at Jules and Catherine's rustic chalet on the Rhine, the men resume their friendship.

Yet things have changed. Though she has given Jules a daughter, Sabine, Catherine has not been domesticated. She has had several lovers, including Albert, the singer who first showed Jules and Jim the statue and who now lives nearby. The stolid Jules fears losing his wife-rightly so, for he's too low-key and dull to keep her-but blames neither Catherine nor Albert. Jim is filled with sadness for Jules, but he is not surprised. When Catherine leads him on a long midnight walk through the woods and tells her side of the story, Jim finds himself inescapably drawn to her. "Was she deliberately seducing him?" the narrator asks. "Jim was not sure. Catherine only revealed what she wanted once she had it in hand." Out of loyalty to his and Jim's friendship and a desire to remain in her presence under any circumstances, Jules renounces his claims on Catherine and tells Jim to marry her. Once more the three set up house together, but this time it is Jim who is sleeping with Catherine, though he otherwise refuses to subject himself to her will.

The new arrangement seems to work for a while-as suggested by Truffaut's creation of an idyllic sequence of bicycle rides, songs, and domino games-but the relationships ineluctably become strained. Jim feels guilty that his friendship with Jules suffers, then jealous when Catherine seduces Jules one evening; Catherine resents the fact that Jim is younger than she and that he returns to Paris to say farewell to Gilberte. Only Jules remains stoic, loving them both. After a series of separations, infidelities, and reconciliations, the love affair between Catherine and Jim is broken off when she suffers a miscarriage and he resolves to marry Gilberte. In a deliberately melodramatic sequence, Catherine pulls a gun on Jim and threatens to shoot him, whereupon he escapes through an open window.

Some time later, Jules and Catherine accidentally meet Jim in Paris at the Cinéma des Ursulines (a favorite haunt of the New Wave group), where a newsreel records the Nazis in the act of burning books. (In Truffaut's Fahrenheit 451 [1965], incidentally, Oskar Werner starred as a man whose duty it is to burn all books, in a society where reading is forbidden.) Though it is now 1934, Jules and Jim have hardly aged in twenty-two years; only Catherine shows the slightest sign of aging: she wears glasses after the war, a delicate touch signifying perhaps that she is slightly older than the men. (Thus does Truffaut visually dramatize one of the film's major themes: the inability of this trio to abandon a stage of youthful idealism in which they hold fast to 
fantasy and romance.) As the two male friends discuss the collapse of their world at an open-air café beside the Seine, Catherine, with a mischievous look in her eye, invites Jim to take a ride in the car with her and tells her husband to watch. She then drives off the edge of a broken bridge into the river, killing them both. (She is both fire and water-two elements with which she has often been identified during the filmchoosing drowning for death, cremation for burial.) For the bewildered Jules, now a widower with a young child, Catherine's death nonetheless brings a great wave of relief. "His friendship with Jim had no equivalent in love," the narrator says.

\section{Circles, Triangles, and Frames}

If the film's plot is one of progressive decline, its images set off such diminutions at every turn. The first enthusiasts of Jules and Jim pointed to the interplay of circles and triangles in its images. The lovers directly illustrate the triangle they are living as they welcome the morning from three separate windows at their home near the sea in the south of France. The sharp angular pans of the camera themselves keep us wondering in which direction love must finally flow. But it is the spinning circularity of the motion-picture projector at the Ursulines that most viewers recall, a circularity repeated in café tables, in a bowl around which tadpoles swim, in Catherine's cosmology that holds the world to be an inverted bowl. Bicycles move in circles; Sabine rolls over and over to the music that culminates in her mother's prophetic song "Le Tourbillon" ("The Whirlwind"), her "rondo of love." Helping to underscore Truffaut's visual ideas about the great circle of life, Raoul Coutard's camera at one point follows a young woman in a bar, does a $360^{\circ}$ pan, and winds up watching Jules draw another girl's face on the surface of a round table.

These two master graphic forms, the circle and the triangle, come together in the hourglass measuring out the final days of La Belle Époque and the preciousness even of the briefest instants of life. Art, by contrast, is a kind of timeless measure, and Jules and Jim is a catalogue of the arts. Scattered throughout its texture are references to old films, to photography and slideshows, to statues, paintings, novels, the theater, and music. This is a story about the drive to raise life to art and art to eternity. That, of course, is one of the reasons both Jules and Jim are artistic types, and in this regard they are as similar as they are different. Jim writes and Jules write, quote, and are much influenced by literature. More important symbolically, and in the context of the romantic aura with which Truffaut surrounds these two men, is that we see both of them using letters to convey their deepest feelings and carry on their most intimate relationships. This element dramatizes their detachment from flesh-and-blood reality (like that of the soldier, known to Jim, who carried on a great romance solely through letters), just as their relationship to the statue on the Greek island emphasizes the mental character of their dealings with Catherine herself.

Truffaut further emphasizes the similarity between Jules and Jim by structuring Albert into the film. For this is no simple love triangle that he has created. Catherine does not simply play Jules off against Jim, or vice versa; rather, she impulsively uses Albert against both of them, as if they were one. Nor does Albert feel about her as Jules and Jim do. Although Albert is willing to marry her and become the father of little Sabine, only Jules and Jim worship Catherine as a goddess. Albert's female counterpart in Jules and Jim is Thérèse, whom Jules encounters at the start before he meets Catherine. Catherine's foil is Thérèse: the latter's game is casual, lighthearted promiscuity. She exploits her own sexuality in order to achieve pleasure, but for her 
such pleasure consists only in a variety of experiences, of carnal adventures. Unlike Catherine, she has no sense of her own importance, no depths; she does not make rules, she only breaks one (fidelity) repeatedly.

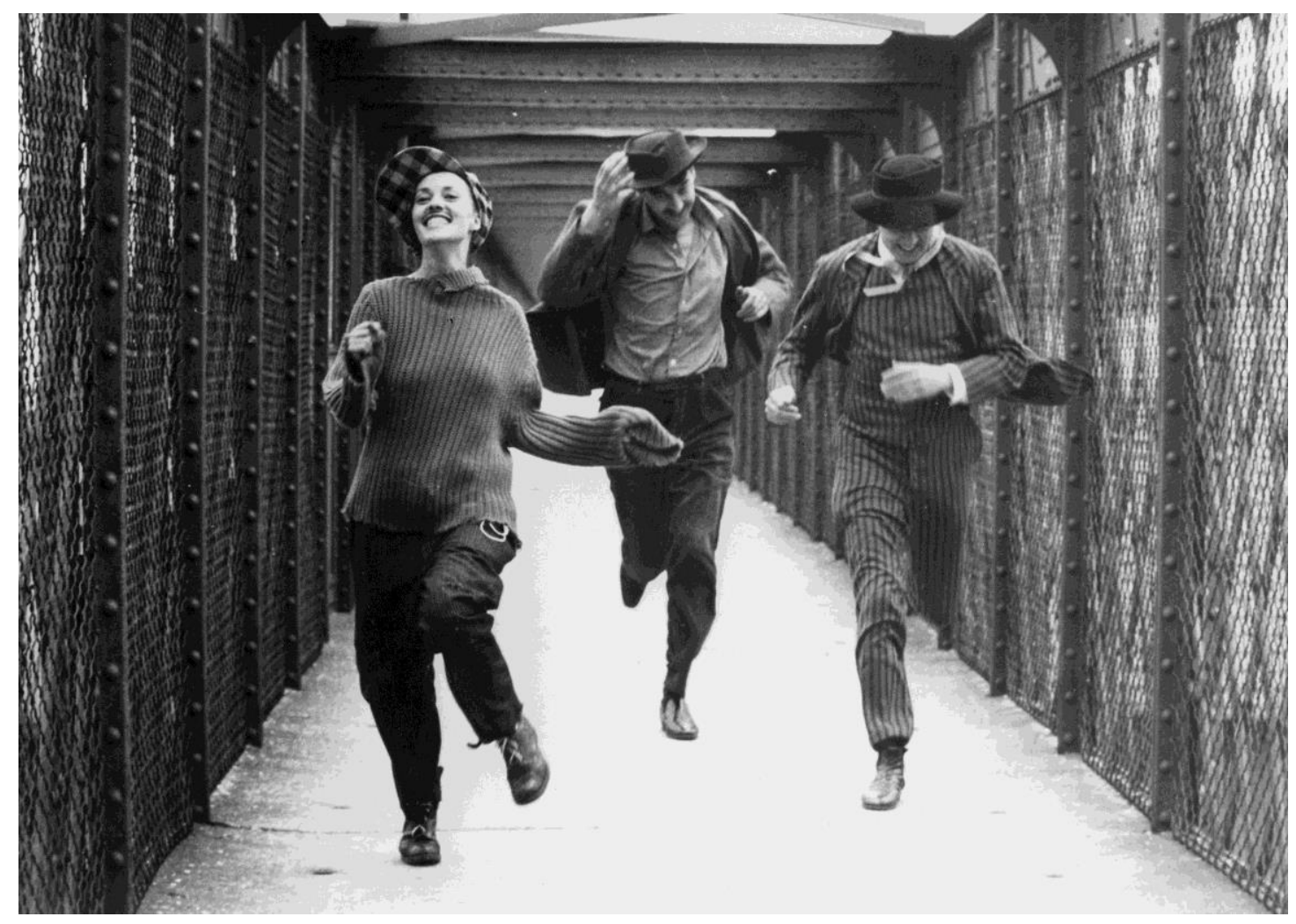

Truffaut's dazzling mixture of cinematic styles and mood shifts in Jules and Jim reinforces the above narrative at every stage. From slapstick humor and witty comedy in the first half of the film to the documentary war footage that divides the narrative in half, to the melodrama that pervades the final reel, Jules and Jim goes beyond merely rehearsing the New Wave's enthusiasm for the myriad possibilities of the medium. For example, the rapid cutting in the opening sequences reflects the joie de vivre of Bohemian Paris before the Great War, in addition to the energy that Jules and Jim invest in their friendship, their writing, and their goddess of love. Similarly, such techniques as mounting the camera on a bicycle to follow the group on their two-wheel jaunts in the countryside, as well as the aerial tracking shots that link the separated lovers, suggest the vitality of their relationship and their efforts to escape or transcend the limits of social conventions and historical circumstances. Truffaut thus takes very seriously, indeed, the adjective in the phrase "motion picture." There is constant movement in his visual images here, particularly in the first part of the film (before World War I). And it is this movement, together with the narrative movement resulting from switches of tone or style, that serves to reflect the irrepressibility of the young protagonists' behavior.

As in the famous concluding shot to The 400 Blows, Truffaut again utilizes the freeze frame - the reverse of physical movement - but with much different effect here. The series of stop-action shots of Catherine early in the film identifies her with the statue that Jules and Jim had first seen on a projected slide; these shots also succeed in "freezing" or immortalizing her statuesque youth or charm, if only momentarily. (By contrast, the jump cuts or elliptical edits in Jules and Jim condense time and thereby suggest not only its ability to "fly," but also its inexorability.) The almost subliminal single freeze-frame shot of the two men reunited after the war is even more compelling, 
preserving the ideal of friendship at the very moment that it seems most precarious. Ultimately, the stylistic eclecticism of Truffaut's Jules and Jim, like that of Renoir's Rules of the Game (1939), expresses a vision of human experience in all its complexity and ambiguity.

\section{Narration, Music, and Meditation}

The voice-over narration itself is an integral part of the film's cinematic style. It serves several important functions. First, such commentary compresses time and leaves the visual images free of the necessity to summarize, through action and dialogue, developing relationships or characterological histories; because the strength of the medium lies in its capacity to picture present-tense action, such a device is crucial in a film whose narrative spans over twenty years. Second, the flat and expressionless (if not somewhat melancholy) tonalities of the voice-over commentary suggest a mature onlooker, an observer whose witness provides balance to the film's headlong rush to tragic conclusion. And third, the narrator's words give us access to Jim's but not Jules's inner thoughts, and thus allow us to follow the track of Jim's seeming good sense- - until they start to chart for us the progress of his fatal involvement with Catherine.

One quality that has been almost universally ascribed to Jules and Jim is its lyricism, its lyric appreciation of life itself. Contributing to this quality is the film's use of music-yet another component of cinematic style. Rarely, however, does Truffaut employ Georges Delerue's music to counterpoint the emotional content of the film's images; instead, music is used here to enhance the visual rhythms synergistically, as when a particular musical theme is associated with the sheer physical exuberance of the romantic triangle. For example, we hear the melodious "joyful" theme first at the seaside villa, when Jules, Jim, and Catherine set off through the woods on the first brilliant morning after their arrival. The music enhances the spontaneous nature of the visuals, which capture the threesome's carefree and ebullient play. Later, we hear the same theme used more subtly at the reunion of the trio after the war; it is also audible as Jim rolls down a hill with Sabine in his arms.

A special musical theme is assigned to Catherine, and it is used with special effectiveness. This is Boris Bassiak's song "Le Tourbillon," which is integrated into the film's dramatic texture. The song is "composed" by Catherine and Albert and sung by her to his guitar accompaniment at the Rhine chalet. The fact that Catherine works on the song suggests something about her character: her will to create, her almost fanatical desire to achieve a certain freedom of expression. In addition, and perhaps more important, the lyrics of "Le Tourbillon" capture and underline the thesis of the interaction between Catherine and all her men:

She had eyes, eyes of opal.

They fascinated me.

Her pale face was an oval.

What a fatal femme was she.

We met with a kiss,

A hit then a miss.

It wasn't all bliss.

And we parted.

We went our ways 
In life's whirlwind of days.

I saw her again one night.

Again, she was an enchanted sight.

This melody is also played at the conclusion of the film, as Jules leaves the cemetery. It signals Catherine's symbolic presence, hence her final victory over both Jules and Jim even as her ashes are interred.

More than a dictionary of cinematic styles, musical and visual, or an entertaining variation on the familiar themes of l'amour fou and the femme fatale-each of which marks the mainstream of Truffaut's work-Jules and Jim is a meditation on art and history, social convention and private morality, love and friendship. In one sense, the film describes the continuous efforts of the central characters (sometimes heroic, sometimes perverse) to make deathless art out of fleeting life, and thereby to overcome the impositions of protean history. Indeed, the passage of time in Jules and Jim is seen through a chronological succession of Picassos, as well as through the insertion of documentary footage. Catherine herself is linked to the enduring or perennial appeal of art by means of her identification with the ancient statue, although in later stages of the picture-when she dons spectacles or, in a profoundly expressive long take, slowly wipes cold cream from her face in front of a dressing-table mirror-she paradoxically comes to represent both timelessness and mutability.

\section{Jules and Jim and Catherine}

For their part, Jules and Jim, who first meet on their way to the Quatres Arts Ball, not only write books (Jim reads from his novel about two friends named Jacques and Julien; after the war, Jules, an entomologist by profession, describes a love story he is planning with insects as characters), they also translate each other's work, as well as discuss Shakespeare, Strindberg, Baudelaire, and Goethe - tellingly, the latter's Elective Affinities (1809). Catherine, however, remains their greatest creation, their eternal muse. When the two men meet for the last time, they lament not only the Nazi book burnings that signify the destruction of the culture they have worshipped, but also their own failure as artists to sustain their vital, human illusion. Perhaps it is because Catherine alone has remained an unregenerate Bohemian, true to the spirit that once bound the three of them together, that she paradoxically decides to save in memory what she can of the love triangle by destroying it in reality.

Like a true goddess ("une vrai femme," Jules calls her), Catherine works in mysterious ways. Indeed, to interpret Jules and Jim requires an understanding of her character, and Truffaut willfully precludes the possibility of definitive analysis or judgment. She can be described as neurotic, tyrannical, immoral, even insane; she can also be seen as a victim of biology, patriarchy, and history. Undoubtedly, Catherine stands as one of the greatest female figures in all of cinema, in large measure because of Jeanne Moreau's remarkable performance. Truffaut himself deserves much of the credit, as well, for taking the risk to film such a script. "The gamble for me," he said, "was to make the woman moving . . . and not a tart, and to prevent her husband from seeming ridiculous" (Bayer, 159). He succeeded by remaining sympathetic to each of his three main characters at the same time that he conveyed an awareness of the impossibility of their quest for absolute freedom-romantic or otherwise. 
The pervasive ambiguity of Jules and Jim may be illustrated by two of its most emotionally moving moments: when Jim first kisses Catherine, and when Catherine returns to her husband's room after quarreling with Jim. In each case, the content of the scene-consummation in the first, reconciliation in the second-is subtly complicated, even subverted, by its cinematic presentation. Let's begin with the consummation scene. From the time very early in the film when Jules invites Jim to visit him and Catherine but pleads, "Not this one, Jim," the narrative has been leading to this climax in which Jim's desire for Catherine overcomes his loyalty to Jules. Truffaut prepares the viewer with several romantic codes or cues: a midnight tryst, Delerue's lush music, soft-focus cinematography, and low-key lighting. As Jim enters the chalet to return Catherine's copy of Goethe's Elective Affinities, she leads him to a window where he traces her silhouetted profile, reaches her mouth, and raises it. A close-up then reveals a fly crawling across the windowpane, and, as Jim bends to kiss Catherine, the small insect appears to light upon her uplifted lips. Thus in a single astonishing moment, Truffaut has poisoned the kiss and, by association with Jules's occupation as an entomologist, has signified the latter's own presence in this dark moment of intimacy.

Another extraordinary example of the film's visual complexity occurs soon afterwards when Catherine crosses the hall to her husband's room to complain about Jim. After he calmly defends his friend and she accuses Jules of despising her, he replies, "No, Catherine, I have never despised you. I shall always love you, whatever you do, whatever happens." To this point, the scene has been composed entirely of alternating shots of the two characters, but now, as they embrace and Catherine tearfully recalls their happy moments together, Truffaut includes them both in a tight close-up. This scene balances, in its intimacy, the earlier one with Jim, but again Truffaut's miseen-scène brilliantly undercuts the close shot's apparent meaning. For, as Catherine kisses Jules, her face fills the screen, threatening to push him off the left edge of the frame. Even at the moment when she appears most vulnerable and affectionate, then, Catherine feels the need to dominate.

In the end, however, Catherine's feelings and desires are defeated by the same destiny that overcomes all human beings. After her death, moreover, she had wanted her ashes scattered to the wind, the narrator relates, but even that "was not permitted" for it was against the rules. Jules and Jim itself endures: a paean to those who dream of living in total freedom, who dare to defy the existing rules, and who, in ultimately failing, nonetheless affirm not only the wonder of all human aspiration and the vitality of life itself, but also life's dreamlike evanescence. Just so, Jean-Paul Sartre once wrote that the greatest art is about the passing of time. Truffaut's Jules and Jim is such a work.

\section{Truffaut, Renoir, and Others}

From the beginning, the film itself was treated precisely as a great work, as a magnificent artistic success, with Truffaut winning praise from such personal heroes as Jean Cocteau and Jean Renoir. He even received a gushing letter from the seventy-fiveyear-old Helen Hessel, the real-life, Seine-jumping model for Catherine who married Jules, became a poet, and, in fact, shot Jim. She told Truffaut that he'd captured on film the essence of the trio's intimate emotions. Such accolades, however, didn't keep France's Commission for the Control of Films from forbidding viewers under the age of eighteen from seeing Jules and Jim because of its "immoral character"-a decision that would be replicated in many other countries. From our present-day vantage point, when nude sex scenes are de rigueur on cable TV, such a decision may seem incredible. But 
this was 1962, and while the New Wave may have been reinventing cinema, French censors weren't ready to reinvent bourgeois morality.

Perhaps a bit naïvely for a Young Turk, Truffaut was shocked by the ban, but he clutched at the nearest straw. The president of the Commission, Henry de Ségogne, told him that its board might reconsider if he could gather a series of laudatory statements concerning Jules and Jim from luminaries. Truffaut set about doing just that, writing to Cocteau, Renoir, and Alain Resnais in request for their support and getting it. Still, despite this illustrious backing, the Commission refused to reverse its original decision, condemning a supposedly immoral movie that would one day be shown in high-school classes. Happily in this case, one man's immorality has become another man's immortality. Vive Jules and Jim . . . and Catherine!

\section{Bibliography and Works Cited}

Allen, Don. Finally Truffaut. Rev. ed. London: Secker \& Warburg, 1985. 86-97.

Andrew, Dudley, \& Anne Gillain, eds. A Companion to François Truffaut. Malden, Mass.: Wiley-Blackwell, 2013.

Armes, Roy. French Cinema since 1946. Vol. 2: The Personal Style. New York: A. S. Barnes, 1966.

Bayer, William. The Great Movies. New York: Grosset \& Dunlap, 1973.

Bergan, Ronald, ed. François Truffaut: Interviews. Jackson: University Press of Mississippi, 2008.

Crisp, C. G. François Truffaut. New York: Praeger, 1972. 58-67.

Gillain, Anne. François Truffaut: The Lost Secret. Trans. Alistair Fox. Bloomington: Indiana University Press, 2013.

Holmes, Diana, \& Robert Ingram. François Truffaut. Manchester, U.K.: Manchester University Press, 1998.

Insdorf, Annette. François Truffaut. New York: William Morrow, 1979.

Le Berre, Carol. François Truffaut at Work. London: Phaidon Press, 2005.

Monaco, James. The New Wave: Truffaut, Godard, Chabrol, Rohmer, Rivette. New York: Oxford University Press, 1976.

Neupert, Richard John. A History of the French New Wave Cinema. Madison: University of Wisconsin Press, 2002.

Petrie, Graham. The Cinema of François Truffaut. New York: A. S. Barnes, 1970.

Roché, Henri-Pierre. Jules and Jim. Trans. Patrick Evans. 1953. New York: Avon, 1963.

Solecki, Sam. A Truffaut Notebook. Montreal: McGill-Queen's University Press, 2015.

Stam, Robert. François Truffaut and Friends: Modernism, Sexuality, and Film Adaptation. New Brunswick, N.J.: Rutgers University Press, 2006.

Truffaut, François. "Une certaine tendance du cinéma français" [A Certain Tendency of French Cinema]. Cahiers du cinéma, 6.31 (Jan. 1954): 15-29.

--------, \& Jean Gruault. Jules and Jim. Trans. Nicholas Fry. London: Lorrimer, 1968.

Truffaut, François. The Films in My Life. Trans. Leonard Mayhew. 1975. New York: Simon \& Schuster, 1978.

--------. Truffaut by Truffaut. Ed. Dominique Rabourdin. Trans. Robert Erich Wolf. 1985. New York: H. N. Abrams, 1987. 
Walz, Eugene P. François Truffaut: A Guide to References and Resources. Boston: G. K. Hall, 1982.

Filmography: Key Films of the French New Wave

La Pointe Courte (1955), directed by Agnès Varda

Bob le flambeur (1956), directed by Jean-Pierre Melville

Elevator to the Gallows (1958), directed by Louis Malle

Le beau Serge (1958), directed by Claude Chabrol

Hiroshima, mon amour (1959), directed by Alain Resnais

The 400 Blows (1959), directed by François Truffaut

The Sign of Leo (1959), directed by Éric Rohmer

Les Cousins (1959), directed by Claude Chabrol

Shoot the Piano Player (1960), directed by François Truffaut

Les Bonnes femmes (1960), directed by Claude Chabrol

Le Petit soldat (1960), directed by Jean-Luc Godard

Breathless (1960), directed by Jean-Luc Godard

Paris Belongs to Us (1961), Jacques Rivette

Last Year at Marienbad (1961), directed by Alain Resnais

Adieu Philippine (1962), directed by Jacques Rozier

Jules and Jim (1962), directed by François Truffaut

Cléo from 5 to 7 (1962), directed by Agnès Varda

Vivre sa vie (1962), directed by Jean-Luc Godard

La Jetée (1962), directed by Chris Marker

Les Carabiniers (1963), directed by Jean-Luc Godard

Contempt (1963), directed by Jean-Luc Godard

Band of Outsiders (1964), directed by Jean-Luc Godard

Alphaville (1965), directed by Jean-Luc Godard

Weekend (1967), directed by Jean-Luc Godard

L'Amour fou (1968), directed by Jacques Rivette

My Night at Maud's (1969), directed by Éric Rohmer

Claire's Knee (1970), directed by Éric Rohmer

The Mother and the Whore (1973), directed by Jean Eustache

Céline and Julie Go Boating (1974), directed by Jacques Rivette

R. J. CARDULLO has had his work appear in such journals as the Yale Review, Cambridge Quarterly, Film Quarterly, and Cinema Journal. For twenty years, from 1987 to 2007, he was the regular film critic for the Hudson Review in New York. Cardullo is the author or editor of a number of books, including Soundings on Cinema: Speaking to Film and Film Artists (SUNY Press, 2008) and In Search of Cinema: Writings on International Film Art (McGill-Queens UP, 2004). He is also the chief American translator of the film criticism of the Frenchman André Bazin. Cardullo's own film criticism has been translated into the following languages: Russian, German, Chinese, Turkish, Spanish, Korean, and Romanian. Cardullo earned his doctoral degree from Yale University and received his B.A. from the University of Florida. He taught for four decades at the University of Michigan, Colgate, and New York University, as well as abroad.

e-mail: robertjcardullo@gmail.com 